\title{
Strategic Entrepreneurship Model for Economic Transformation: Malaysian Evidence
}

\author{
Amran Awang ${ }^{1}$, Azizan Kassim ${ }^{1}$, Azura Mohd Noor ${ }^{2}$, Najihah Shukor ${ }^{1}$, Ahmad Zakhwan Shaari ${ }^{1}$, Shazwani \\ Amran $^{1}$, Sarah Mardhiah Selamat ${ }^{1} \&$ Shaiful Annuar Khalid ${ }^{1}$ \\ ${ }^{1}$ Faculty of Business and Management, University of Technology MARA (UiTM), Perlis Campus, Malaysia \\ ${ }^{2}$ Faculty of Accountancy, University of Technology MARA (UiTM), Perlis Campus, Malaysia \\ Correspondence: Amran Awang, Faculty of Business and Management, University of Technology MARA \\ (UiTM), Perlis Campus, 02600 Arau Perlis, Malaysia. E-mail: amranawang@yahoo.com
}

Received: January 15, 2015 Accepted: February 26, 2015 Online Published: March 16, 2015

doi:10.5539/ass.v11n7p19 URL: http://dx.doi.org/10.5539/ass.v11n7p19

\begin{abstract}
The study examines input-process-output model of strategic entrepreneurship among the Malaysian SMEs entrepreneurs. The study justified resource inputs (environment, organizational and individual) are important resources for firms' output. The study examines 46 entrepreneurs in the community in cross-sectional analysis. The results indicate that the model uphold the resource-based view (RBV) theory that environmental, organizational and individual resources determine better SMEs' economic performance in Malaysia. Research limitations, common method bias and future studies are also discussed.
\end{abstract}

Keywords: strategic entrepreneurship, environmental resources, organizational resources, individual resources, competitive advantage, value creation, job creation, wealth creation, economic transformation, SMEs, Malaysia

\section{Introduction}

Inquiry in strategic entrepreneurship has steadily entered into entrepreneurship study since early 2000 when Hitt, Keats and Yucel (2003) proposed a conceptual framework in their textbook. However, much still unknown in capitalizing SE as a body of knowledge in entrepreneurship literatures. Most of the studies (e.g. Shepherd \& Wilklund, 2009; Schindehutte \& Morris, 2009; Hitt, Ireland, Sirmon, \& Trahm, 2011) reiterated that SE has considerable impact on firms' growth, competitive advantage, opportunity advantage, value and wealth creation.

SE is an integrative model of strategic management and entrepreneurship whereby they capitalize on firms' behavioral aspect that will transform their internal resources (transforming its product, markets, internal processes and so on) to a better future and higher industrial standard (Hitt et al., 2011). Covin and Miles (1999) explain SE may take any one of the five forms, "strategic renewal, sustained regeneration, domain redefinition, organizational rejuvenation, and business model reconstruction" (p. 54).

Works in SE begin to take some forms filling basic gaps, especially in concept and model development (Hitt et al., 2011). Among others a model of Ireland, Hitt and Sirmon (2003) proposed four dimensions (1) the entrepreneurial mindset, culture and leadership, (2) the strategic management of organizational resources, (3) application of creativity, and (4) development of innovation invites further inquiry. Kyrgidou and Hughes (2010) criticized the model as lacking in robustness required in capturing the gestalt of SE. Supporting the argument there were studies suggesting the model to uphold SE as broader in scope, multilevel and more dynamic compared to original conceptualization (Chiles, Bluedorn, \& Gupta, 2007; Hitt, Beamish, Jackson, \& Mathieu, 2007; Rindova, Barry, \& Ketchen, 2009). Recently, Hitt et al. (2011) proposed input-processes-output (I-P-O) model of SE that incorporates multilevel and more general domain, environmental influences, resource orchestration (RO) and three levels of outcome.

This paper verifies Hitt et al. (2011) input and output variables within Malaysian SMEs. A preliminary analysis among 46 small and medium firms justifies the instruments appropriate for the model. Analysis on direct relationships executed in testing the hypothesis. The study explores relationships that substantiate RBV and subsequently help in delineating which resources appropriate to enhance our nation's competitive advantage, job creation, value creation, wealth creation and economic transformation. 


\section{Research Issues}

The quests for sound research instruments are always treated as a major factor before research results finalized. Study in SE has been a recent phenomenon where most of the literature were mainly seminal and conceptual, thus gap for construct and measurement development are essential for relationship inquiry. Moreover, limited study found investigating on relationship between input-output models of strategic entrepreneurship. We propose the research question as follows; 1) how does individual, organizational and environmental construct delineate into SE dimensions. 2) How do SE input factors explain the output factors?

\section{Strategic Management, Entrepreneurship and Economic Performance}

Kuratko, Ireland and Hornsby (2001) argued that the integration of entrepreneurship and strategic management could enhance and speed up firms' direction towards their goals. Both concepts predict better firm performance. But, specifically strategic management focuses on organizations' continuous renewal and growth. Even though major component of strategic management is plan formulation in managing firms' external opportunities and threats in the purview of firms' internal strengths and weaknesses, but it is also a way of thinking i.e. 'strategic thinking' in search of new sources of competitive advantage (Kuratko \& Audretsch, 2009).

On the other hand, Ronstadt (1984) reiterated that entrepreneurship is a dynamic process of creating incremental wealth. Entrepreneurs execute the process by taking the risks in value creation of new or existing product or service. The study on entrepreneurship observes steady growth after David Cantillon (1755), Knight (1921) and Schumpeter (1934) proposed creative destruction concept, risk, uncertainty and economic development theory respectively. Entrepreneurship concept walks through multiple paths looking for an identity (Jennings, 1994). Several examples traced back since early 1900 assimilate entrepreneur as a private business owner (Tuttle, 1927), other scholarly work in entrepreneurship associates entrepreneur as a manifestation of a 'heffalump' (Kilby, 1971). Furthermore in the 80s Vesper (1980) defined entrepreneur as an individual, and entrepreneurship as firm behavior (Gartner, 1989). Firm performance as the outcome entrepreneurship entered into scholarly publications since late 70s such as studies of Khandwalla (1977) and Miller (1983).

Both strategic management and entrepreneurship is argued as drivers in economic development (Cole, 1959; Agarwal, Audrestch \& Sarker, 2007; Carree \& Thurik, 2008). Agarwal et al. (2007) cited that strategic management of places or also known as economic development policy primarily focuses on strategic entrepreneurship to uphold innovation and growth. Caree and Thurik (2008) noted that the rediscovery of entrepreneurial primacy as a contributor to economic growth, job creation, and competitiveness in global markets.

However, Dolfsma and de Panne (2008) replicated Acs and Audretsch study in 1988 and discovered contrary result that when firms were getting larger they became less innovative, a phenomenon justified in Schumpeter (1942) innovation theory. Thus Schumpeter argument on economic development and SMEs now lend substantial supports (Kirchoff, 1994; Dolfsma \& de Panne, 2008; Stawasz \& Glodek, 2010).

\section{Strategic Entrepreneurship Model}

The strategic entrepreneurship's I-P-O (Note 1) model is multilevel that includes both opportunity and advantage-seeking behaviors reflected in environment, organization and individual level (Hitt et al., 2011). These inputs determine the resource orchestration that subsequently creating value for societies, organizations and individuals as shown in Figure 1 in Appendix A.

On the other hand, SE is the integration of strategic management and entrepreneurship (Hitt et al., 2011). Earlier studies in strategic management noted in Andrew (1961), Chandler (1962), Ansoff (1963) barely touched on entrepreneurship as a strategic factor in organization. However, these theories evolved through complexities in a competitive landscape in search of competitive advantage (Porter, 1985) that recently intersected with entrepreneurial perspective as a new domain in recent business landscape. SE is expected to explain wealth and value creation in the presence of opportunity and ultimately secured the competitive advantage (Hitt et al., 2011).

The input dimensions include environmental factors, organizational factors and individual resources. The SE processes that require firms to act entrepreneurially in the orchestration of its resources where besides protecting and exploiting existing resources the firm explores into new and value-creating resources. The concept of resource orchestration is highlighted in recent research that suggests effective strategic entrepreneurship requires organizational leaders to acquire, organize, and deploy resources for optimal advantage (Ndofor, Sirmon, \& He, 2011; Sirmon, Hitt, \& Ireland, 2007; Chirico, Sirmon, Sciascia, \& Mazzola 2011). Such activities highlight the value of using resources to both explore and exploit entrepreneurial opportunities (Hitt et al., 2011). 


\section{The Resources Manifestation}

Entrepreneurship and strategy literature provide endless lists of factors that manifest as resources or inputs that explain a firm's higher performance and sustainability. However, which resources were more important in terms of rarity, value, inimitable and no close substitute have been clarified in Penrose's (1959) resource base theory (RBT), and further elaborated in Wernerfelt (1984) and Barney (1991) then termed as a resource-based view (RBV). This newer version of resources imperatives prove that the intangibles one were always superior due to its nature of value creator, rareness, inimitability and absent of close substitutes (Grant, 1996).

Environmental factors, organizational and individual resources in combined form cited as managed resources in Ireland et al. (2003), resource orchestration in Hitt et al. (2011) and Chirico et al. (2011). The operationalization of resource orchestration has been quite extensive when it involves three key dimensions of structuring, bundling and leveraging.

Each input has been discussed in Ireland et al. (2003) and Hitt et al (2011). The external environmental is a resource that facilitates firm in identifying, acquiring and exploiting resources. These resources include tangibles such as raw materials, financial capital, labor and customers. The intangibles include those assets such as tacit knowledge in a particular area. Other facilitating environmental factor is dynamic that creates uncertainty. Some studies proved dynamic environment were positively related to new venture formation (Aldrich, 2000), and in Wang and $\mathrm{Li}$ (2008) proved dynamic environment explained higher innovation in simulation of exploration.

Organizational resources reside in the firm's strategic posture, and thus firm level dimensions of innovativeness, proactiveness and risk-taking behavior proved substantial in determining enhanced and sustained SMEs performance (Awang et al., 2009; Covin \& Slevin, 1991; Lumpkin \& Dess, 1996). These entrepreneurship dimensions have been part and parcel of the corporate entrepreneurship concept (Block \& MacMillan 1995; Covin \& Miller, 1999; Dess et al., 1999; Guth \& Ginsberg, 1990) that shaped entrepreneurial behavior in larger firms through internal corporate venturing (ICV).

Individual resources as mentioned and conceptualized in Ireland et al. (2003) proposed that both tangible and intangible resources were suitable for strategic entrepreneurship. Entrepreneurial mindset refers to an intended thought process of entrepreneurs towards business and opportunities and consciously aware of the presence of uncertainties in the environment (Hitt et al., 2003). In addition, Doepfer (2013) relates entrepreneurial mindset with competencies of entrepreneurs in identifying opportunities, strategizing and organizing. Another perspective that molds entrepreneurial mindset has been due to the culture that supports entrepreneurial thinking. Other individual resources include the balancing of knowledge exploration and exploitation (Rezaian \& Naeiji, 2012). The intangible capitals are manifested in human, structural, relational and social (Miller \& Buys, 2008; Rezaian \& Naeiji, 2012). Knowledge exploration and exploitation always capitalize on creating resources superior to competitors (Revilla et al., 2008; Lumpkin, Steier, \& Wright, 2011). Earlier study in SE found in Hitt et al. (2001) proposed that the integration of entrepreneurial opportunity-seeking and strategic advantage seeking actions requires firms to change existing operations.

\section{Strategic Entrepreneurship and SMEs Economic Performance}

The study extents knowledge established in strategic management that competitive advantage and value creation have been the core issues (Chen, Fairchild, Freeman, Harris, \& Venkataraman, 2010). In addition, other studies such as Ketchen, Ireland \& Snow (2007) and Porter (1980) noted that the main factor in determining firms' ability to create value and wealth for stakeholders and society was the effective competitive positioning. In similar vein, we argue that strategic entrepreneurship may provide fertile ground for a nation's economic performance. The economic domains worth further inquiry are such as job creation and economic transformation plan.

Malaysian ETP plays a pivotal role in enhancing the country towards a developed nation in 2020 or earlier. Initial indicators prove few achievements; however, some economic objectives remain unachieved, such as the 30 percent participation of the Bumiputera in country's economic sectors which showed just about 20 percent achievement (Malaysia, 2010).

SMEs roles in economic transformation involve their actions in reinventing themselves. Oxford Economics (2013) suggested the process includes revenue generation should come from outside their home country, do a significant change to their business model and operation, develop human capital either groom employees with growth capabilities or recruit right candidates. However, role of SMEs in economic transformation remain largely unresolved worldwide (Herrendorf, Herrington, \& Valentinyi, 2013), referring to economic growth 
remains imbalance on inappropriate input, human capital misallocation, sectoral unleniency and resource misallocation issues.

Hence, we posit:

H1: SE individual, organizational and environmental inputs are delineated in specific factors

H2: There is a positive relation between environmental inputs and SMEs economic performance

H3: There is a positive relation between organizational inputs and SMEs economic performance

H4: There is a positive relation between individual inputs and SMEs economic performance

\section{Research Model}

Three input factors comprise of environmental, organizational and individual resources determine the SMEs economic outputs factors namely the competitive advantage, value creation, wealth creation, job creation and economic transformation. Part of input-process-output model is the modified model proposed in Hitt et al. (2011). Refer the research model in Figure 1 in Appendix A.

\section{Methodology}

\subsection{Sampling}

Sample of the study comprise of those established small and medium sized enterprises (SMEs) in Malaysia. Established SMEs are those with more than 10 employees, the firms have distinct and separate departments, established at least within five years in operation and endow capital more than RM250, 000. There were about 10 percent of the SME's population in Malaysia are within this category.

Sampling utilizes simple random sampling to render quantitative data from the observation among the selected sample. The population frame establishes from list of SMEs identified in various authorities such as MARA, Agrobank, MADA, and KADA. Ensuring representative sample size calculation is executed as suggested in Berenson (2001). Principle of sampling in ensuring each SME to have equal chance to be selected, sample selection then utilizes random number table to identify numbers of SMEs in the population frame respectively until the sample size identified is achieved. From population frame as listed number of sample (n) is then selected whereby a sample frame then established. The ' $n$ ' denotes the sample size derives through estimation of sampling error (SE). The sampling error estimates the rate of variability in the observations. Other factor considered in the estimation is the confident level that usually set at $p<.05$ or 95 percent confident level. Thus the smaller the variability, the lesser sample size derived.

The pilot study utilizes majority of about 55 percent male entrepreneurs, they were mostly among younger age respondents about 60 percent representation. About 70 percent of the respondents were those that passed high school to master degree. Fifty percent of the respondents were the owner manager of the firms and the rest were managers. The firms existence period used in pilot study were about equally distributed where half have been in operation more than 5 years and the other half were less than 5 years. However, most of the firms were small sized where about 90 percent employed less than 50 employees. About 70 percent of the firms were sole proprietor while the rest were private limited and joint ventures. Types of business were mainly services where only about 20 percent were manufacturer and mixed type. The demographic distribution is as listed in Table 1 in Appendix B.

\subsection{Measurement and Instruments}

Second is to operationalize the construct into measurable instruments, the operationalization will take at least two steps to execute a pilot study that preliminary verify the validity and reliability of the construct items.

\subsubsection{Strategic Entrepreneurship and Antecedents}

The measurement for inputs of SE was adopted from number of studies in Rezaian and Neiji (2012) and Naldi et al. (2011). Strategic entrepreneurship as a three-factor concept: entrepreneurial mindset, balancing exploration and exploitation, and continuous innovation (Ireland et al., 2003; Ireland \& Webb, 2009). The term "mindset" refers to "the cognitive frameworks through which fresh and existing knowledge is interpreted and used to inform decisions such as those regarding strategy and entrepreneurship" (Baron, 2007). The second dimension of strategic entrepreneurship is to find a balance between exploration and exploitation (Ireland et al., 2003). This dimension is the centerpiece of strategic entrepreneurship concept and researches have shown that this balancing will contribute to achieving superior performance (Huang, 2009). The third key element is continuous innovation that occurs when an enterprise continuously creates or transfers economic value. Therefore, continuous innovation directly and positively contributes to a firm in creating wealth. In sum, the strategic entrepreneurship 
discussed above offers new ideas to develop and exploit a firm's strategy in pursuing competitive advantages. Please refer Figure 2 in Appendix A.

In addition, Naldi et al. (2011) utilized knowledge resources as the rate companies' endowment of the following knowledge resources for the previous three years: 1) technology know-how, 2) manufacturing know-how, 3) marketing know-how, 4) distribution know-how and 5) human resources.

\subsubsection{SMEs Economic Performance}

The concept of competitive advantage cannot be boiled down to a formula or a ratio; furthermore, distinguishing between competitive advantage and operational efficiency is often difficult. Harvard Business School Professor Michael Porter, in his excellent essay, "What Is Strategy?" (1996), argues that these two concepts must not be confused: operational effectiveness means a company is better than rivals at similar activities while competitive advantage means a company is performing better than rivals by doing different activities or performing similar activities in different ways. Investors should know that few companies are able to compete successfully for long if they are doing the same things as their competitors.

On the other hand, a national economic transformation utilizes measures from Floud (1984) in a study that measures European economic transformation. Floud (1984) gauges national income as an indicator. United Nations G-20 (2011) indicates that job creation, wealth creation and SMEs' global participation of a country were among indicators of a national economic transformation for developing countries.

The instruments used in the research are summarized in Table 1 (Refer Appendix B). Most of the items were adapted from number of sources and some items were self developed. All research instruments were on a 7-point scale. Wealth creation and economic transformation were self develop after considering some information in the literature (Madden, 2007; UN G-20, 2011).

\subsection{Common Method Bias (CMB)}

We run the Harman one factor test as suggested in Podsakoff, MacKenzie, Lee \&Podsakoff (2003) as an indicator that proved significant different between constructs used in the study. The EFA was run on each input variable and output variable in one factor that showed the variance explained on the factor were less than .50. The results proved all measures were free from CMB. Realizing the effect of CMB that could harm data early precaution was taken by formulating the instruments adapted from different sources (Podaskoff et al., 2003).

\section{Results}

The results were analyzed in three stages, first, the descriptive analysis. Second, verify the goodness of measures through construct validity and reliability analysis. And third, the inferential analysis utilized multiple regressions.

\subsection{Descriptive Statistics}

The descriptive observed that the respondents in the study were 54 percent male representation. The age bracket was younger where 73 percent represented by those less than 50 years. Education level was 94 percent was among those with undergraduate degree and below. Most of the respondents were middle managers represented by 83 percent. Most of them have been in the firm for more than 3 years to more than 20 years showed about 76 percent representation. Refer Table 2 in Appendix C.

The firm descriptive showed 65 percent were in service business where 91 percent employed less than 20 employees. Most of the firms were 65 percent registered in proprietorship form. The details are shown in Table 2 in Appendix C.

\subsection{Construct Validity}

Exploratory factor analysis (EFA) was utilized to verify the construct validity of the items used in the questionnaire. The EFA utilized the principal component analysis (PCA) and rotated using the orthogonal approach of varimax rotation. Individual input comprised of entrepreneurial mindset, balancing exploration, knowledge exploration and exploitation were explained by more than $60 \%$ of the total variance with 4 items loaded significantly on each variables as suggested.

The organizational input factors comprised of corporate entrepreneurship, human capital, social capital, relational capital, entrepreneurial culture and leadership observed corporate entrepreneurship loaded on 6 items (4 items were removed due to low measures of sampling adequacy and communality less than .50) with $61 \%$ of variance explained. The 19-items intellectual capital construct loaded on three factors of human, social and relational capital explained by $70 \%$ of the variance with 15 items ( 4 items were removed due as above) however, 
the structural capital was denied as a factor. Entrepreneurial culture and leadership construct observed $69 \%$ of the variance with only one item removed due to low measures of sampling adequacy.

The environmental input factors observed 14-items construct loaded on three factors of environmental uncertainty, dynamism and complexity explained by $69 \%$ of the variance with 2 items were removed. The results of EFA are tabulated in Table 3 in Appendix D.

Thus, $H 1$ was substantiated that the three SE input factors were delineated according to specific factors.

\subsection{Variable Descriptive}

EFA helps segregate items according to specific factors shown in the value of each factor loading. Items loaded in each factor then went through reliability analysis indicated in Cronbach's alpha. Ensuring reliable alpha, some items were dropped that the measures achieved .70 at least as suggested in Nunnally (1981). Table 4 lists down the scores of each variable in the study (please refer Appendix E).

The results proved that some of the relationships as suggested in the proposal were substantial. Table 4 in Appendix F exhibits the measures of central tendency, reliability and correlation analysis of all variables in the study.

\subsection{Inferential Analysis}

The relationships between variables were run at lower order multiple regression analysis. Table 5 exhibited the direct MRA between independent and dependent variables. The technique applied as suggested in Hair et al. (2006).

\subsubsection{Direct Relationship}

Individual resource dimensions have sufficient variance in explaining four economic performances except wealth creation output. Specifically, both competitive advantage and economic transformation showed positive relations with balancing exploration and knowledge exploration dimensions at $p<.01$. On the other hand, balancing exploration and knowledge exploitation explained higher value creation and knowledge exploration explained higher job creation. However, entrepreneurial mindset and knowledge exploitation showed negative relation with job creation and competitive advantage respectively.

Organizational resources proved four economic performance dimensions achieved sufficient variance in the coefficient of determination except wealth creation output. Corporate entrepreneurship explained higher competitive advantage, job creation and economic transformation dimensions. Each social capital and entrepreneurial culture showed positive relation with values creation and economic transformation respectively. On the other hand, human capital was negatively related to economic transformation.

Environmental resource dimensions showed sufficient variance to explain SMEs economic performance dimensions. Environmental dynamism explained higher competitive advantage and job creation. On the other, environmental uncertainty explained higher value creation and economic transformation. And subsequently, environmental complexity explained higher wealth creation and economic transformation.

The summary of relationship between SE input variables and SMEs economic performance was presented in Table 5 in Appendix F. Thus all $H 2, H 3$ and $H 4$ were partially supported.

\section{Discussion and Conclusion}

The preliminary analysis with small sample proves the construct validity and reliability of each variable was substantiated. The EFA clears the distinctiveness of each variable that justifies the research question and hypothesis. Hence SE antecedents were verified inherent within the individual, organizational and environmental paradigm as discussed in Kuratko and Audrestch (2009), and Hitt et al. (2011). The data clears some issue regarding the intercorrelation when no extreme relationships found in the Pearson $R$ correlation coefficients.

We manage to verify some interesting findings in relationships between variables in Hitt et al. (2011) SE model. Most of the direct relationships were statistically verified in significant $F$ value at $p<.05$. The coefficient of determination proved most of them achieved sufficient variance in explaining the SMEs economic performance variables. Specifically, relationship between SE input factors and outcome variables that showed two insignificant models. The findings suggest RBV (Barney, 1991) substantiated as inputs of environmental, organizational and individual resources pertinent in ensuring higher SMEs economic outcomes.

The study addressed issues on making SMEs more strategic and sustained their entrepreneurial state. These challenges prevailed in upholding SMEs central function as establishers of competitive advantage, creators of value, wealth, job and a nation's economic transformers. 
This paper suggests preliminary findings based on a small group of SMEs restricted in one location. Thus interpreting the data should be done with the utmost care in generalizing the results. First, most of the observations were based on nascent firms at their early stage of strategy making and execution. Second, the observations were based on thought processes of one locality that exercised in one particular business area. Future studies shall capitalize on extended data from wider area and locality with more diverse strategy making process and execution.

\section{Acknowledgements}

The study is indebted to various quarters, especially to the sponsoring body of Malaysian Ministry of Education's Exploratory Research Grant Scheme (ERGS) that supports with sufficient fund and opportunity. Second, the appreciation goes to the coordinating body, the Universiti Teknologi MARA (UiTM) Research Management Institute (RMI) which helps in ensuring the project schedule and management always on track.

\section{References}

Agarwal, R., Audretsch, D., \& Sarkar, M. B. (2007). The process of creative construction: Knowledge spill overs, entrepreneurship, and economic growth. Strategic Entrepreneurship Journal, 263-286. http://dx.doi.org/ $10.1002 /$ sej.36

Aldrich, H. (2000). Organization Evolving. London: Sage.

Andrew, M. (1961). Strategic Management: A Dynamic Perspective Concepts (2nd ed.). New York: Pearson Prentice Hall.

Ansoff, I. (1963). Corporate Strategy. Harmondsworth: Penguin.

Audretsch, D. B., Lehmann, E. E., \& Plummer, L. A. (2009). Agency and governance in strategic entrepreneurship. Entrepreneurship Theory and Practice, 33(1), 149-166. http://dx.doi.org/10.1111/j.15406520.2008.00284.x

Awang, A., Khalid, S. A., \& Yusof, A. (2009). Entrepreneurial Orientation and Performance Relation among SMEs: The Impact of Some Perceived Environment. International Journal of Business Management, 4(9), 84-96. http://dx.doi.org/10.5539/ijbm.v4n9p84

Barney, J. B (1991). Firm resources \& sustained competitive advantages. Journal of Management, 17(1), 99-120. http://dx.doi.org/10.1177/014920639101700108

Baron, R. A. (2007). Behavioral and cognitive factors in entrepreneurship: Entrepreneurs as the active element in new venture creation. Strategic Entrepreneurship Journal, 1(1-2), 167-182. http://dx.doi.org/10.1002/sej.12

Block, Z., \& MacMillan, I. C. (1995). Corporate venturing: Creating new business within the firm. Boston, MA: Harvard Business Press.

Cabrita, M., \& Vaz, J. (2006). Intellectual capital and value creation: Evidence from the Portuguese banking industry. The Electronic Journal of Knowledge Management, 4(1), 11-20.

Cantillon, R. (1755 [2001]). Essaisur la nature du commerce en general (English ed.). Piscataway, NJ: Transaction Publishers.

Carree, M., \& Thurik, R. (2008). The lag structure of the impact of business ownership on economic performance in OECD countries. Small Business Economics, 30, 101-110. http://dx.doi.org/10.1007/ s11187-006-9007-0

Chandler, A. D. (1962). Strategic and Structure: Chapters in the History of the American Industrial Enterprise. Beard Books: Washington.

Chiles, T., Bluedorn, A. C., \& Gupta, V. K. (2007). Beyond creative destruction and entrepreneurial discovery: A radical Austrian approach to entrepreneurship. Organization Studies, 28(4), 467-493. http://dx.doi.org/10.1177/0170840606067996

Chirico, F., Sirmon, D. G., Sciascia, S., \& Mazzola, P. (2011). Resource Orchestration in Family Firms: Investigating How Entrepreneurial Orientation, Generational Involvement, \& Participative Strategy Affect Performance. Strategic Entrepreneurship Journal, 5, 307-326. http://dx.doi.org/10.1002/sej.121

Cole, A. (1959). Business enterprise in its social setting. Cambridge, MA: Harvard University Press.

Covin, J. G., \& Miles, M. P. (1999). Corporate entrepreneurship and the pursuit of competitive advantage. Entrepreneurship Theory and Practice, 23(3), 47-65. 
Covin, J. G., \& Slevin, D. P. (1991). A conceptual model of entrepreneurship as firm behaviour. Entrepreneurship Theory and Practice, 16(1), 7-25.

Dess, G. G., Lumpkin, G. T., \& McGee, J. E. (1999). Linking corporate entrepreneurship to strategy, structure, and process: Suggested research directions. Entrepreneurship Theory and Practice, 23(3), 85-102.

Doepfer, B. C. (2013). Co-Innovation Competence. In A Strategic Approach to Entrepreneurship in Regional Innovation Structures (pp. 73-111). Springer Fachmedien Wiesbaden.

Dolfsma, W., \& der Panne, G. V. (2008). Currents and sub-currents in innovation flows: Explaining innovativeness using new-product announcements. Research Policy, 37(10), 1706-1716. http://dx.doi.org/10.1016/j.respol.2008.08.009

Edward, S., \& Pawel, G. (2010). SMEs Innovation and Job Creation Potential in the Shadow Economy Context. Comparative Economic Research, 99-105.

Floud, R. C. (1985). Measuring the Transformation of the European Economies: Income, Health, and Welfare. Historical Social Research, 71, G-20 (2011)

Gartner, W. B. (1989). Some suggestions for research on entrepreneurial traits and characteristics. Entrepreneurship: Theory and Practice, fall, 14(1), 27-38.

Gomez-Mejia, L. R., Haynes, K., Nunez-Nickel, M., Jacobson, K., \& Moyano-Fuentes, J. (2007). Socioemotional wealth and business risks in family controlled firms: evidence from Spanish olive oil mills. Administrative Science Quarterly, 52, 106-137.

Gomez-Mejia, L., Cruz, C., Berrone, P., \& De Castro, J. (2011). The bind that ties: Socioemotional wealth preservation in family firms. Academy of Management Annals, 5, 653-707. http://dx.doi.org/10.1080/ 19416520.2011.593320

Grant, R. M. (1996). Toward a Knowledge-Based Theory of the Firm. Strategic Management Journal, 17, 109-122. http://dx.doi.org/10.1002/smj.4250171110

Gupta, V., Macmillan, I. C., \& Surie, G. (2004). Entrepreneurial Leadership: Developing and Measuring a Cross-cultural Construct. Journal of Business Venturing, 19(2), 241-260. http://dx.doi.org/10.1016/S08839026(03)00040-5

Guth, W. D., \& Ginsberg, A. (1990). Guest editors' introduction: Corporate entrepreneurship. Strategic Management Journal, 11(5), 5-15.

Hair, J. F., Black, W. C., Babin, B. J., Anderson, R. E., \& Tatham, R. L. (2006). Multivariate data analysis (6th ed.). Englewood Cliffs, NJ: Pearson/Prentice Hall.

Herrendorf, B., Herrington, C., \& Valentinyi, A. (2013). Sectoral technology and structural transformation. Mimeo, Arizona State University. http://dx.doi.org/10.3386/w18996

Hitt, M. A., Beamish, P. W., Jackson, S. E., \& Mathieu, J. E. (2007). Building theoretical and empirical bridges across levels: Multilevel research in management. Academy of Management Journal, 50, 285-311. http://dx.doi.org/10.5465/AMJ.2007.28166219

Hitt, M. A., Ireland, R. D., \& Hoskisson, R. E. (2011). Strategic Management: Competitiveness and Globalization (9th ed.). Mason, OH: Thomson South-Western.

Hitt, M. A., Ireland, R. D., Camp, S. M., \& Sexton, D. L. (2001). Strategic entrepreneurship: Strategies for wealth creation. Strategic Management Journal, 22(3-4), 479-491. http://dx.doi.org/10.1002/smj.196

Hitt, M. A., Keats, B. W., \& Yucel, E. (2003). Strategic leadership in global business organizations: Building trust and social capital. In W. H. Mobley, \& P. Dorfman (Eds.), Advances in Global Leadership (Vol. 3, pp. 9-35). Greenwich, CT: JAI Press.

Huang, H. C. (2009). Designing a knowledge-based system for strategic planning: A balanced scorecard perspective. Expert System with Application, 36, 209-218. http://dx.doi.org/10.1016/j.eswa.2007.09.046

Ireland, R. D., \& Hitt, M. A. (2005). Achieving and maintaining strategic competitiveness in the $21^{\text {st }}$ century: The role of strategic leadership. Academy of Management Executive, 19(4), 65-77. http://dx.doi.org/10.5465/AME.2005.19417908

Ireland, R. D., \& Webb, J. (2009). Crossing the great divide of strategic entrepreneurship: Transitioning between exploration and exploitation. Business Horizons, 52(2), 469-479. http://dx.doi.org/10.1016/j.bushor.2009. 05.002 
Ireland, R. D., Hitt, M. A., \& Sirmon, D. G. (2003). A Model of Strategic Entrepreneurship: The Construct and its Dimensions. Journal of Management, 29, 963-989. http://dx.doi.org/10.1016/S0149-2063(03)00086-2

Ireland, R. D., Hitt, M. A., Camp, S. M., \& Sexton, D. L. (2001). Integrating entrepreneurship and strategic management action to create firm wealth. Academy of Management Executive, 15(1), 49-63. http://dx.doi.org/10.5465/AME.2001.4251393

Jalali, A. (2012). Dirty statistical models (Doctoral Dissertation). University of Texas, Austin.

Jennings, D. F. (1994). Multiple Perspectives of Entrepreneurship. Ohio: South Western Publishing.

Ketchen, D. J., Ireland, R. D., \& Snow, C. C. (2007). Strategic Entrepreneurship, Collaborative Innovation, and Wealth Creation. Strategic Entrepreneurship Journal, 1(3-4), 371-385. http://dx.doi.org/10.1002/sej.20

Khandwalla, P. (1977). The Design of Organizations. New York: Harcourt Brace Jovanovich.

Kilby, P. (1971). Entrepreneurship and Economic Development. New York: Free Press.

Kirchhoff, B. A. (1994). Entrepreneurship and Dynamic Capitalism, The Economics of Business Firm Formation and Growth. Westport, CT: Greenood Publishing.

Knight, F. (1921). Risk, Uncertainty and Profit. New York: Augustus Kelley.

Koberg, C. S., Detienne, D. R., \& Heppard, K. A. (2003). An Empirical Test of Environmental, Organizational and Process Factors Affecting Incremental and Radical Innovation. Journal of High Technolgy Management Research, 14, 21-45. http://dx.doi.org/10.1016/S1047-8310(03)00003-8

Kuratko, D. F., \& Audretsch, D. B. (2009). Strategic entrepreneurship: Exploring different perspectives of an emerging concept. Entrepreneurship Theory and Practice, 33(1), 1-17. http://dx.doi.org/10.1111/j.15406520.2008.00278.x

Kuratko, D. F., Ireland, R. D., \& Hornsby, J. S. (2001). Improving firm performance through entrepreneurial actions: Acordia's corporate entrepreneurship strategy. Academy of Management Executive, 15(4), 60-71. http://dx.doi.org/10.5465/AME.2001.5897658

Kyrgidou, L. P., \& Hughes, M. (2010). Strategic Entrepreneurship: Origins, Core Elements and Research Directions. European Business Review, 22, 43-63. http://dx.doi.org/10.1108/09555341011009007

Lumpkin, G. T, Steier, L., \& Wright, M. (2011). Strategic entrepreneurship in family business. Strategic Entrepreneurship Journal, 5, 285-306. http://dx.doi.org/10.1002/sej.122

Lumpkin, G. T., \& Dess, G. G. (1996). Clarifying the entrepreneurial orientation construct and linking it to performance. The Academy of Management Review, 21(1), 135-172.

Mahoney, J. (2010). After KKV: The New Methodology of Qualitative Research. World Politics Review, 62(1), 120-147. http://dx.doi.org/10.1017/S0043887109990220

Makri, M., Hitt, M. A., \& Lane, P. J. (2010). Complementary technologies, knowledge relatedness, and invention outcomes in high technology mergers and acquisitions. Strategic Management Journal, 31(6), 602-628

Malaysia. (2010). Economic Report 2010. Malaysian Printers and Publication Limited.

Meuleman, M., Amess, K., \& Wright, M. (2009). Agency, strategic entrepreneurship and the performance of private equity backed buyouts. Entrepreneurship Theory and Practice, 33(1), 213-240.

Meyer, K. (2009). Corporate strategies under Pressures of Globalization: Global focusing. Retrieved from http://www.klausmeyer.co.uk

Miller, D. (1983). The correlates of entrepreneurship in three types of firms. Management Science, 29(7), 770-791. http://dx.doi.org/10.1287/mnsc.29.7.770

Miller, E., \& Buys, L. (2008). Retrofitting commercial office buildings for sustainability: Tenants' perspectives. Journal of Property Investment \& Finance, 26(6), 552-561. http://dx.doi.org/10.1108/14635780810908398

Monsen, E., \& Boss, R. W. (2009). The impact of strategic entrepreneurship inside the organization: examining job stress and employee retention. Entrepreneurship Theory and Practice, 33(1), 71-104.

Munikrishnan, U. T. (2009). Job creation in small, micro and medium enterprises (SMMTEs). TEAM Journal of Hospitality \&Tourism, 6(1), 12-23.

Naldi, A., Remy, E., Thieffry, E., \& Chaouiya, C. (2011). Dynamically consistent reduction of logical regulatory graphs. Theoretical Computer Science, 412(21), 2207-2218. http://dx.doi.org/10.1016/j.tcs.2010.10.021 
Ndofor, H. A., Sirmon, D. G., \& He, X. (2011). Firm resources, competitive action and performance: Investigating a mediated model with evidence from the In-vitro diagnostic industry. Strategic Management Journal, 32, 640-657. http://dx.doi.org/10.1002/smj.901

Nguyen, T. N. Q. (2010). Knowledge management capability and competitive advantage: an empirical study of Vietnamese enterprises (Doctoral Dissertation). Southern Cross University, NSW.

Nunnally, J. C. (1967). Psychometric Theory. New York, NY: McGraw-Hill Book Company.

Patzelt, H., \& Shepherd, D. A. (2009). Strategic entrepreneurship at universities: Academic entrepreneurs' assessment of policy programs. Entrepreneurship Theory \& Practice, 33(1), 319-340. http://dx.doi.org/10.1111/j.1540-6520.2008.00291.x

Penrose, E. T. (1959). The Theory of the Growth of the Firm. John Wiley \& Sons: New York.

Podsakoff, P. M., MacKenzie, S. B., Lee, J.-Y., \& Podsakoff, N. P. (2003). Common method biases in behavioral research: A critical review of the literature and recommended remedies. Journal of Applied Psychology, 88, 879-903. http://dx.doi.org/10.1037/0021-9010.88.5.879

Porter, M. E. (1985). Competitive Advantage. New York: Free Press.

Revilla, D. J., Schiller, D., Liefner, I., \& Bromer, C. (2008). Agile firms and their spatial organisation of business in the greater Pearl River Delta. Die Erde, 139(3), 251-269.

Rezaian, A., \& Javad, M. N. (2012). Strategic entrepreneurship and intellectual capital as determinants of organizational performance: Empirical evidence from Iran steel industry. Journal of Global Entrepreneurship Research, 17-32.

Rezvani, M., \& Khazaei, M. (2013). Prioritization of entrepreneurial marketing dimensions a case of in higher education institutions by using entropy. International Journal of Information, Business \& Management, 5(3), 30 .

Rindova, V., Barry, D., \& Ketchen, D. (2009). Entrepreneuring as emancipation. Academy of Management Review, 34(3), 477-491. http://dx.doi.org/10.5465/AMR.2009.40632647

Schindehutte, M., \& Morris, M. H. (2009). Advancing strategic entrepreneurship research: The role of complexity science in shifting the paradigm. Entrepreneurship Theory and Practice, 33, 241-276. http://dx.doi.org/10.1111/j.1540-6520.2008.00288.x

Schumpeter, J. A. (1934). The Theory of Economics Development. Cambridge, MA: Harvard University Press.

Schumpeter, J. A. (1942). Capitalism, Socialism and Democracy. Harper and Row, New York.

Shepherd, D., \& Wiklund, J. (2009). Are we comparing apples with apples or apples with oranges? Appropriateness of knowledge accumulation across growth studies. Entrepreneurship Theory and Practice, 33(1), 105-123. http://dx.doi.org/10.1111/j.1540-6520.2008.00282.x

Sirmon, D. G., \& Hitt, M. A. (2003). Managing resources: Linking unique resources, management, and wealth creation in family firms. Entrepreneurship Theory and Practice, 27, 339-358.

Sirmon, D. G., Hitt, M. A., \& Ireland, R. D. (2007). Managing firm resources in dynamic environments to create value: Looking inside the black box. Academy of Management Review, 32(1), 273-292. ttp://dx.doi.org/10.5465/AMR.2007.23466005

Sirmon, D. G., Hitt, M. A., Ireland, R. D., \& Gilbert, B. A. (2011). Resource orchestration to create competitive advantage: breadth, depth, and life cycle effects. Journal of Management, 37(5), 1390-1412. http://dx.doi.org/10.1177/0149206310385695

SMEs: Equipped to Compete. (2013). Oxford Economics. Retrieved from http://www.oxfordeconomics.com/ publication/open/242447

Statistics Department Malaysia. (2011). Population Distribution and Basic Demographic Characteristic Report 2010. Retrieved from http://www.statistics.gov.my/portal/index.php?option=com_content\&id=121518

Surroca, J., Tribo, J. A., \& Waddock, S. (2010). Corporate Responsibility and Financial Performance: The Role of Intangible Resources. Universidad Carlos III de Madrid, Madrid, Spain.

Tuttle, C. (1927). The entrepreneur function in economic literature. Journal of Political Economy, 35, 501-521. http://dx.doi.org/10.1086/253873

UN G20. (2011). The Future of the G20 and its Place in Global Governance. Retrieved from 
http://www.cigionline.org/sites/default/files/g20no5.pdf

Vesper, K. H. (1980). New venture planning. Journal of Business Strategy, 1(2), 73-75. http://dx.doi.org/10.1108/eb038903

Wang, H., \& Li, J. (2008). Untangling the effects of over exploration and overexploitation on organizational performance: The moderating role of environmental dynamism. Journal of Management, 34(5), 925-951. http://dx.doi.org/10.1177/0149206308321547

Webb, T. L., Sniehotta, F. F., \& Michie, S. (2010). Using theories of behaviour change to inform interventions for addictive behaviours. Addiction, 105, 1879-1892. http://dx.doi.org/10.1111/j.1360-0443.2010.03028.x

Wernerfelt, B. (1984). A Resource-based view of the firm. Strategic Management Journal, 5, 171-180. http://dx.doi.org/10.1002/smj.4250050207

Zahra, S. A., Rawhouser, H. N., Bhawe, N., Neubaum, D. O., \& Hayton, J. C. (2008). Globalization of social entrepreneurship opportunities. Strategic Entrepreneurship Journal, 2(2), 117-131.

Note

Note 1. The IPO model was first proposed in Tableau Economique by Francois Quesenay (1758) adapted by Leon Walras a century later and Wassily Leontif won the Nobel price in 1973 after simplifying the Walras theoretical formulation.

\section{Appendix A}

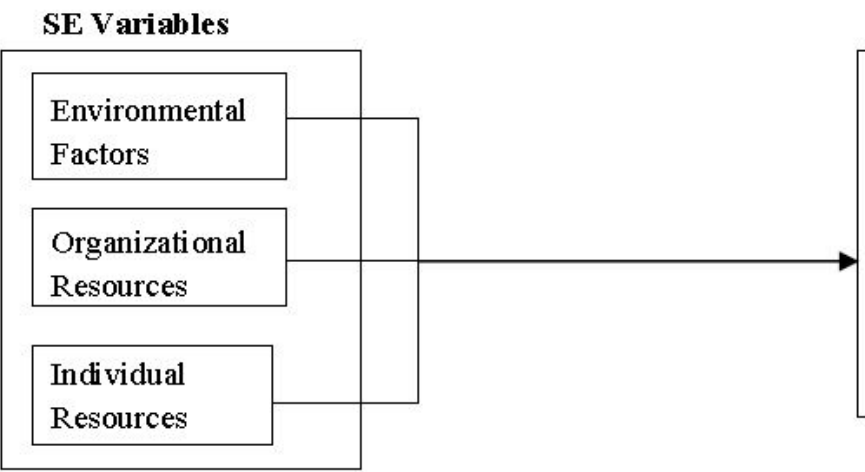

The outcome variables

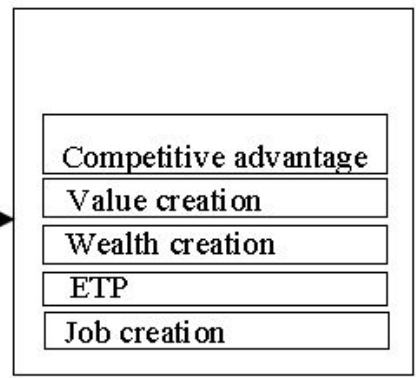

Figure 1. Model of strategic entrepreneurship (Source: Hitt et al., 2011).

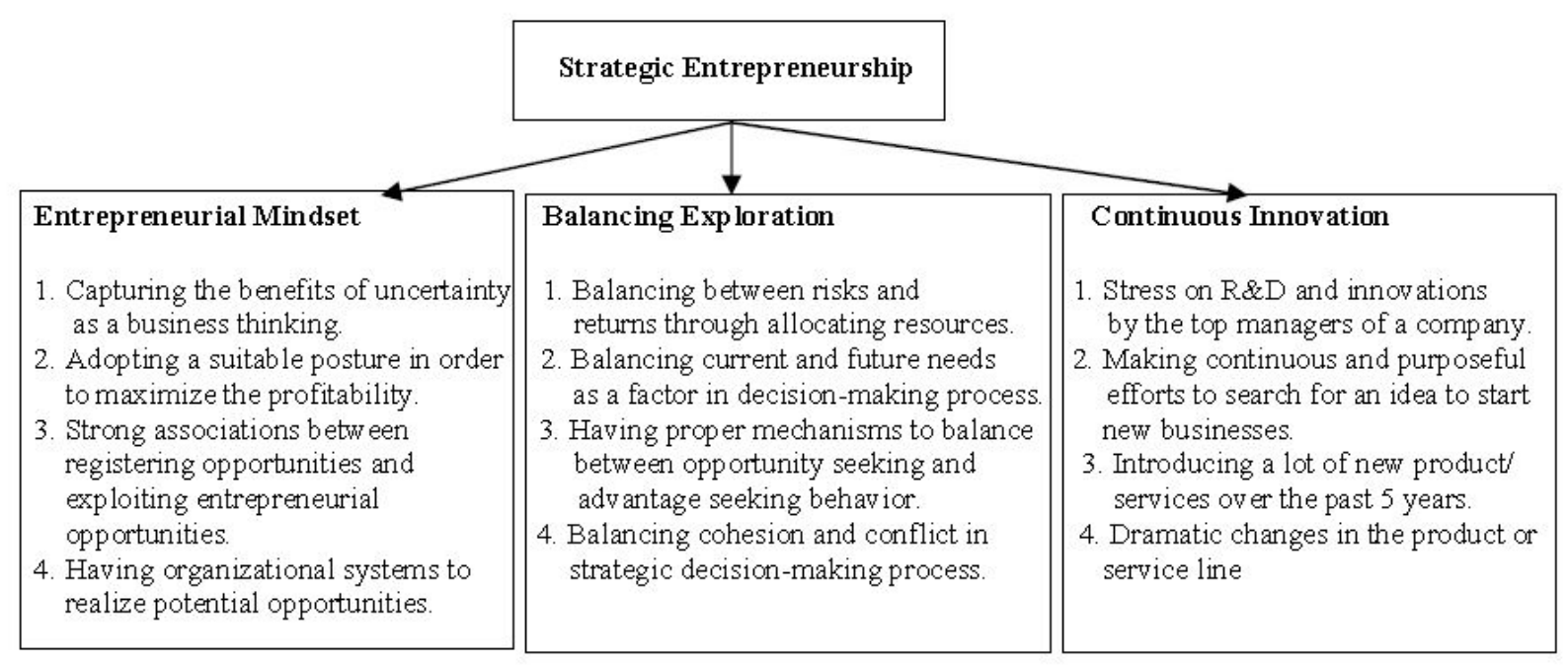

Figure 2. Operationalizing SE. (Source: Rezaian \& Naeiji, 2012) 


\section{Appendix B}

Table 1. Research Items of I-P-O Model of SE

\begin{tabular}{|c|c|c|c|}
\hline Variable & Number of Item & Source & \\
\hline \multicolumn{4}{|l|}{ Input } \\
\hline Entrepreneurial Mindset & 4 & Rezaian \& Neiji (2012) & $(\alpha=.79)$ \\
\hline Balancing Exploration & 4 & -do- & $(\alpha=.74)$ \\
\hline Innovativeness - EO & 3 & Jalali (2012) & $(\alpha=.88)$ \\
\hline Proactiveness - EO & 3 & - do- & $(\alpha=.79)$ \\
\hline Risk Taking - EO & 3 & -do- & $(\alpha=.89)$ \\
\hline Knowledge Exploration & 4 & Revilla et al. (2008) & $(\alpha=.83)$ \\
\hline Knowledge Exploitation & 4 & - do- & $(\alpha=.87)$ \\
\hline Human Capital & 5 & Rezaian \& Neiji (2012) & $(\alpha=.81)$ \\
\hline Structural Capital & 4 & -do- & $(\alpha=.78)$ \\
\hline Relational Capital & 4 & -do- & $(\alpha=.80)$ \\
\hline Social Capital & 6 & Miller \& Buys (2008) & $(\alpha=.83)$ \\
\hline Entrepreneurial leadership & 3 & Gupta et al. (2004) & $(\alpha=\mathrm{na})$ \\
\hline Entrepreneurial culture & 4 & Kuratko \& Audrestch (2009) & $(\alpha=\mathrm{na})$ \\
\hline Environmental Factors & & Koberg et al. (2013), Revilla et al. (2008) & \\
\hline Dynamism & 4 & $(\alpha=.73)$ & \\
\hline Uncertainty & 3 & $(\alpha=.68)$ & \\
\hline Complexity & 3 & $(\alpha=.84)$ & \\
\hline Munificence & 4 & $(\alpha=.65)$ & \\
\hline \multicolumn{4}{|l|}{ Output } \\
\hline Competitive Advantage & 4 & Nguyen (2010) & $(\alpha=.71)$ \\
\hline Value Creation & 4 & Rezvani \& Khazaei (2013) & $(\alpha=.75)$ \\
\hline Job Creation & 4 & Munikrishnan (2009) & $(\alpha=.96)$ \\
\hline Wealth Creation & 4 & Madden (2007) & $(\alpha=\mathrm{na})$ \\
\hline Economic Transformation & 4 & UN G-20 (2011) & $(\alpha=n a)$ \\
\hline
\end{tabular}

\section{Appendix C}

Table 2. Demographic descriptive

\begin{tabular}{ll}
\hline Variable & Percent \\
\hline Gender & 54.3 \\
Male & 39.1 \\
Female & 26.1 \\
Age & 30.4 \\
Less than 30 years old & 26.1 \\
30-40 years old & 10.9 \\
41-50 years old & 2.2 \\
51-60 years old & 26.1 \\
More than 60 years old & 19.6 \\
Education level & 50.2 \\
High school & 4.3 \\
Diploma & 0 \\
Undergraduate & 2.3 \\
Masters & \\
PhD/Doctorate & 6.5 \\
Others & 10.9 \\
Current position & 28.3 \\
CEO & 15.2 \\
Managing Director & 2.2 \\
General Manager & \\
Sales/Marketing Manager & \\
Finance/Accounting Manager & \\
\hline
\end{tabular}




\begin{tabular}{ll}
\hline Variable & Percent \\
\hline Human Resource Manager & 0 \\
R\&D Manager & 0 \\
Information Technology Manager & 0 \\
Operations/Production Manager & 8.7 \\
Others & 23.9 \\
Years Work & \\
Less than 1 year & 15.2 \\
1-2 years & 8.7 \\
3-5 years & 28.3 \\
6-10 years & 17.4 \\
11-20 years & 17.4 \\
More than 20 years & 8.7 \\
Number of employees & \\
Less than 20 & 91.3 \\
20-49 & 2.2 \\
50-199 & 2.2 \\
200-299 & 0 \\
300-499 & 0 \\
500 and over & 0 \\
Type of ownership & 0 \\
Sole Proprietor & \\
Private Limited & 65.2 \\
Public Limited & 19.6 \\
Joint Venture & 0 \\
100\% Foreign Owned & 6.5 \\
Others & 0 \\
Primary industry & 4.3 \\
Manufacturing & \\
Service & 4.3 \\
Mixed & 65.2 \\
\hline
\end{tabular}

\section{Appendix D}

Table 3. Exploratory factor analysis

\begin{tabular}{lcc}
\hline \multicolumn{1}{c}{ Variable/Item } & $\begin{array}{c}\text { KMO, Bartlett Test } \\
\text { of Sphericity \& DF }\end{array}$ & $\begin{array}{c}\text { Construct/(\% of total variance)/ } \\
\text { Factor loading or coefficients }\end{array}$ \\
\hline Entrepreneurial mindset & $.75,88.65^{* *}, 6$ & $(66.39)$ \\
Capture benefit of uncertainty & & $\mathbf{. 9 3}$ \\
Register and exploit opportunities & & $\mathbf{. 9 3}$ \\
Adopt a posture to maximize profitability & & $\mathbf{. 8 8}$ \\
Possess organizational systems & $.80,85.51^{* *}, 6$ & $\mathbf{. 4 0}$ \\
Balancing exploration & & $\mathbf{( 7 2 . 3 7 )}$ \\
Balance current \& future need & & $\mathbf{. 9 1}$ \\
Balance opportunity \& advantage seeking & & $\mathbf{. 8 7}$ \\
Balance risk \& returns through & $.74,132.66^{* *}, 15$ & $\mathbf{. 8 1}$ \\
Balance cohesion \& conflict in DM & & $\mathbf{. 8 1}$ \\
Corporate Entrepreneurship & & $\mathbf{6 1 . 1 1 )}$ \\
Stress on R\&D \& innovation & $\mathbf{. 2 3}$ \\
Continuous efforts for idea & & $\mathbf{. 1 7}$ \\
Introduce new products in 5 years & $\mathbf{. 2 2}$ \\
Create dramatic changes in products & & $\mathbf{. 2 4}$ \\
First to initiate action that competitor react & & $\mathbf{. 2 2}$ \\
First to introduce new products & & $\mathbf{. 1 9}$ \\
Knowledge exploration (Explore) & $.79,193.32^{* *}, 28$ & Explore (32.14) \\
Detect and make correction to problems & & $\mathbf{. 9 2}$ \\
\cline { 2 - 3 }
\end{tabular}




\begin{tabular}{|c|c|c|c|c|}
\hline Variable/Item & $\begin{array}{l}\text { KMO, Bartlett Test } \\
\text { of Sphericity \& DF }\end{array}$ & \multicolumn{3}{|c|}{$\begin{array}{l}\text { Construct } /(\% \text { of total variance }) / \\
\text { Factor loading or coefficients }\end{array}$} \\
\hline Cover customers' problem areas & \multirow{17}{*}{$.85,463.15^{* *}, 105$} & .87 & & .09 \\
\hline Make use of existing competence & & .73 & & .38 \\
\hline Identify valuable knowledge elements & & .60 & & .30 \\
\hline \multicolumn{5}{|l|}{ Knowledge exploitation (Exploit) } \\
\hline Introduce new knowledge \& method & & .01 & & .91 \\
\hline Produce new \& useful ideas & & .25 & & .76 \\
\hline Lesson learned put into operation & & .45 & & .73 \\
\hline Integrate new \& existing ways in tasks & & .53 & & .61 \\
\hline Human capital (HC) & & $\mathrm{HC}(44.13)$ & $\mathrm{SC}(14.88)$ & $\mathrm{RC}(11.71)$ \\
\hline Respect differ in culture and individual & & .90 & .20 & .01 \\
\hline Establish family and friend connection & & .90 & .18 & .02 \\
\hline Ensure guest's complaints are settled & & .87 & .15 & .03 \\
\hline Instills feeling of trust & & .85 & .10 & .17 \\
\hline Establishes neighborhood connection & & .85 & .13 & .15 \\
\hline Increase knowledge across dept. & & .80 & .08 & .23 \\
\hline Develop \& share knowledge & & .80 & .12 & .22 \\
\hline Develop cooperation across dept. & & .79 & -.03 & .21 \\
\hline Improvise consumer satisfaction & & .79 & .16 & .12 \\
\hline \multicolumn{5}{|l|}{ Social capital (SC) } \\
\hline Relationship with commercial partners & & .15 & .83 & .21 \\
\hline Participate in local community & & .14 & .80 & -.06 \\
\hline Employ good qualified employees & & .17 & .71 & .11 \\
\hline \multicolumn{5}{|l|}{ Relational capital (RC) } \\
\hline Develop appropriate reward system & \multirow{8}{*}{$.68,96.33^{* *}, 15$} & .26 & .18 & .74 \\
\hline Requires work experience & & -.11 & .42 & .71 \\
\hline More valuable brand than competitors & & .32 & -.19 & .66 \\
\hline Entrepreneurial culture (Cult) & & Cult (45.71) & \multicolumn{2}{|c|}{ Lead (23.36) } \\
\hline Emphasize courage confidence hope & & .94 & \multicolumn{2}{|c|}{-.01} \\
\hline Focus on good interpersonal relations & & .89 & \multicolumn{2}{|r|}{.10} \\
\hline Never experience lack of idea & & .75 & \multicolumn{2}{|r|}{-.36} \\
\hline Focus on improving firm's services & & .70 & \multicolumn{2}{|r|}{-.20} \\
\hline \multicolumn{5}{|l|}{ Entrepreneurial leadership (Lead) } \\
\hline Unusual ability to persuade & \multirow{9}{*}{$.65,267.28^{* *}, 66$} & -.16 & \multicolumn{2}{|r|}{.82} \\
\hline Many promising ideas & & -.01 & \multicolumn{2}{|r|}{.74} \\
\hline Environmental Uncertainty (U) & & $\mathrm{U}(29.41)$ & $\mathrm{D}(24.75)$ & $\mathrm{C}(14.78)$ \\
\hline Influence of external environment & & .80 & .02 & .36 \\
\hline Level of process complexity & & .80 & .25 & -.17 \\
\hline Technology change and opportunity & & .78 & .20 & .14 \\
\hline Level of technological change & & .76 & -.11 & .21 \\
\hline Level of product complexity & & .75 & .09 & -.03 \\
\hline Ability to get skilled labor & & .56 & -.28 & .56 \\
\hline \multicolumn{5}{|l|}{ Environmental drynamism (D) } \\
\hline Accessibility to financial capital & & -.04 & .83 & -.04 \\
\hline Knowledge intensity in product dev. & & .21 & .78 & .01 \\
\hline Level of customer's preference changes & & -.05 & .77 & .16 \\
\hline New product through breakthrough tech. & & .29 & .69 & .13 \\
\hline \multicolumn{5}{|l|}{ Environmental complexity (C) } \\
\hline Ability in utilizing managerial talent & \multirow{7}{*}{$.65,172.19^{* *}, 28$} & .20 & .18 & .86 \\
\hline Stability in economic external environment & & -.13 & .61 & .68 \\
\hline Competitive advantage (CA) & & \multicolumn{3}{|c|}{$\mathrm{VC}(29.88)$} \\
\hline Capabilities difficult to duplicate & & .86 & & -.22 \\
\hline Always to consider IP protection & & .84 & & -.16 \\
\hline Committed in env. preservation & & .76 & & .19 \\
\hline Use $\mathrm{KM}$ to widen product array & & .73 & & .18 \\
\hline
\end{tabular}




\begin{tabular}{|c|c|c|c|c|}
\hline Variable/Item & $\begin{array}{l}\text { KMO, Bartlett Test } \\
\text { of Sphericity \& DF }\end{array}$ & \multicolumn{3}{|c|}{$\begin{array}{l}\text { Construct } /(\% \text { of total variance }) / \\
\text { Factor loading or coefficients }\end{array}$} \\
\hline Market position create strong barrier & & \multicolumn{2}{|l|}{.72} & .51 \\
\hline \multicolumn{5}{|l|}{ Value Creation (VC) } \\
\hline Often uses K-Based innovation & & .06 & & .91 \\
\hline Our products provide great benefits & & -.18 & & .82 \\
\hline Always consider well being of people & & .18 & & .71 \\
\hline Economic transformation (ET) & \multirow[t]{6}{*}{$.75,433.85 * *, 66$} & ET (33.07) & $\mathrm{JC}(27.27)$ & WC (17.36) \\
\hline Contribute to NKEA & & .92 & .22 & .09 \\
\hline Our firm is substantial to METP & & .90 & 28 & .11 \\
\hline Employees were ETP well informed & & .85 & 17 & 27 \\
\hline Allocate $\%$ of income for community & & .85 & .07 & .09 \\
\hline Affect changes due to ETP & & .78 & -.02 & 21 \\
\hline \multicolumn{5}{|l|}{ Job creation (JC) } \\
\hline Created substantial nos. of new positions & & .05 & .89 & .30 \\
\hline Added substantial nos. of employees & & .14 & .89 & -.01 \\
\hline Provide wide senior position oppotunities & & .15 & .86 & .13 \\
\hline Wealth creation (WC) & & .16 & .83 & -.16 \\
\hline We pay divident every year & & .18 & .14 & .93 \\
\hline We pay income tax every year & & .21 & .09 & .90 \\
\hline
\end{tabular}

\section{Appendix E}

Table 4. Measures of central tendency and correlation analysis

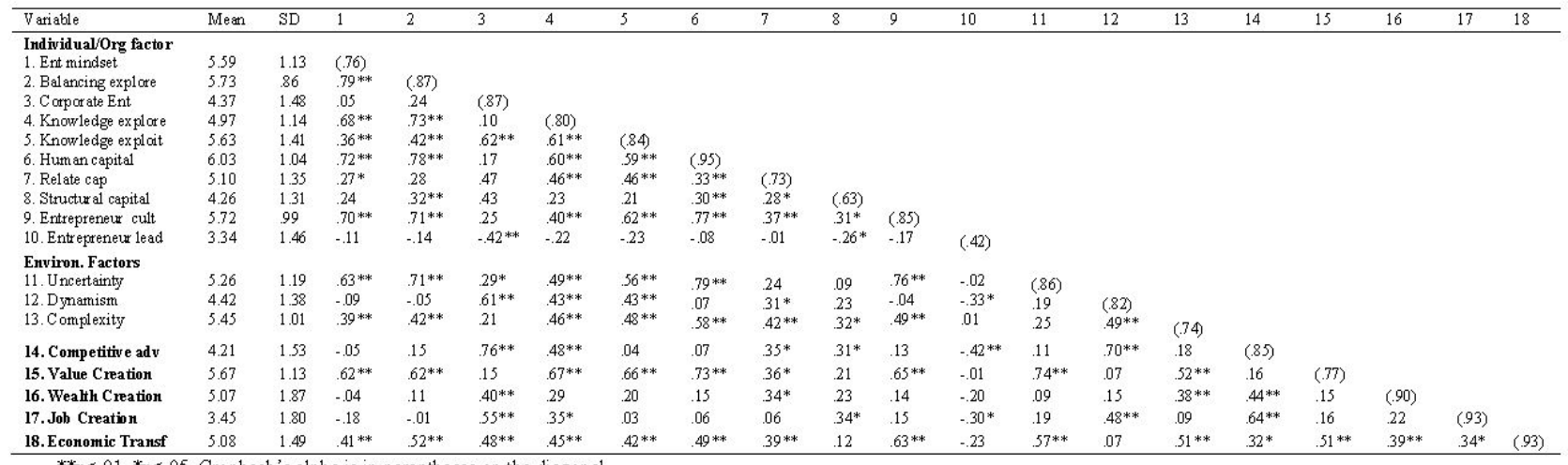

$* *_{p}<.01, * p<.05$, Cronbach's alpha is in parantheses on the diagonal.

\section{Appendix F}

Table 5. SE input and resource orchestration

\begin{tabular}{|c|c|c|c|c|c|c|c|c|c|c|}
\hline & \multicolumn{2}{|c|}{ Competitive Advantage } & \multicolumn{2}{|c|}{ Value Creation } & \multicolumn{2}{|c|}{ Wealth Creation } & \multicolumn{2}{|c|}{ Job Creation } & \multicolumn{2}{|l|}{ ETP } \\
\hline & $\mathrm{B}$ & SE & $\mathrm{B}$ & SE & $\mathrm{B}$ & SE & $\mathrm{B}$ & $\mathrm{SE}$ & $\mathrm{B}$ & SE \\
\hline \multicolumn{11}{|l|}{ Individual resources } \\
\hline Intercept & 1.62 & 1.29 & .55 & .78 & 2.47 & 1.82 & 2.21 & 1.65 & -1.23 & 1.05 \\
\hline Entrepreneurial mindset & -.50 & .28 & .02 & .17 & -.78 & .40 & $-.80 *$ & .36 & -.30 & .23 \\
\hline Balancing exploration & $1.00 * *$ & .40 & $.55 *$ & .24 & .77 & .56 & .75 & .51 & $1.32 * *$ & .32 \\
\hline Knowledge exploration & $.77 * *$ & .17 & -.02 & .10 & .13 & .40 & $.64 * *$ & .22 & $.36^{*}$ & .14 \\
\hline Knowledge exploitation & $-.75^{* *}$ & .29 & $.38 *$ & .17 & .37 & .24 & -.31 & .37 & -.23 & .23 \\
\hline Adjusted R2 & .37 & & .55 & & .09 & & .21 & & .48 & \\
\hline F-Value & $7.12 * *$ & & $13.64 * *$ & & $2.13^{\mathrm{ns}}$ & & $3.76^{*}$ & & $10.61 * *$ & \\
\hline SEE & 1.23 & & .74 & & 1.73 & & 1.56 & & .99 & \\
\hline Durbin Watson & 1.74 & & 2.16 & & 1.78 & & 2.31 & & 1.80 & \\
\hline \multirow{3}{*}{$\begin{array}{l}\text { Organizational resources } \\
\text { Intercept } \\
\text { Corporate Ent }\end{array}$} & $\mathrm{B}$ & SE & $\mathrm{B}$ & SE & $\mathrm{B}$ & SE & $\mathrm{B}$ & SE & $\mathrm{B}$ & SE \\
\hline & 2.18 & 1.21 & .03 & .95 & 2.39 & 2.14 & .78 & 1.80 & -.94 & 1.24 \\
\hline & $.73 * *$ & .14 & -.02 & .11 & .30 & .25 & $.76^{* *}$ & .21 & $.44 * *$ & .14 \\
\hline
\end{tabular}




\begin{tabular}{|c|c|c|c|c|c|c|c|c|c|c|}
\hline Relationship capital & .07 & .15 & .11 & .11 & .32 & .42 & -.38 & .21 & .03 & .15 \\
\hline Social capital & -.03 & .24 & $.59 * *$ & .18 & .12 & .26 & -.14 & .35 & .06 & .24 \\
\hline Human capital & -.04 & .14 & -.02 & .11 & .06 & .24 & .20 & .20 & $-.28 *$ & .14 \\
\hline Entrepreneurial culture & -.13 & .25 & .27 & .19 & -.15 & .44 & .19 & .37 & $.82 * *$ & .25 \\
\hline Entrepreneurial leadership & -.16 & .12 & .05 & .10 & -.13 & .22 & .04 & .19 & .01 & .13 \\
\hline Adjusted R2 & .54 & & .51 & & .07 & & .28 & & .49 & \\
\hline F-Value & $9.66 * *$ & & $8.51 * *$ & & $1.56^{\mathrm{ns}}$ & & $3.74 * *$ & & $7.93 * *$ & \\
\hline SEE & 1.03 & & .80 & & 1.82 & & 1.51 & & 1.06 & \\
\hline Durbin Watson & 1.41 & & 2.07 & & 1.62 & & 2.28 & & 2.04 & \\
\hline Environmental resources & $\mathrm{B}$ & SE & $\mathrm{B}$ & SE & $\mathrm{B}$ & SE & $\mathrm{B}$ & SE & $\mathrm{B}$ & SE \\
\hline Intercept & .87 & .98 & $1.37 *$ & .66 & 2.56 & 1.55 & .19 & 1.39 & .46 & 1.04 \\
\hline Dynamism & $.79 * *$ & .13 & -.10 & .09 & .09 & .21 & $.63 * *$ & .19 & -.11 & .14 \\
\hline Uncertainty & -.05 & .19 & $.70 * *$ & .13 & -.29 & .29 & .24 & .27 & $.58 * *$ & .20 \\
\hline Complexity & .01 & .17 & .19 & .11 & $.70 * *$ & .26 & -.17 & .24 & $.37 *$ & .18 \\
\hline Adjusted R2 & .45 & & .56 & & .11 & & .19 & & .35 & \\
\hline F-Value & $13.18 * *$ & & $19.45 * *$ & & $2.79 *$ & & $4.44 * *$ & & $8.75 * *$ & \\
\hline SEE & 1.12 & & .76 & & 1.78 & & 1.59 & & 1.19 & \\
\hline Durbin Watson & 1.81 & & 2.52 & & 1.47 & & 2.21 & & 2.06 & \\
\hline
\end{tabular}

$* * p<.01, * p<.05, \mathrm{~ns}=$ not significant.

\section{Copyrights}

Copyright for this article is retained by the author(s), with first publication rights granted to the journal.

This is an open-access article distributed under the terms and conditions of the Creative Commons Attribution license (http://creativecommons.org/licenses/by/3.0/). 